\title{
Perancangan Desain Produk dengan Inspirasi Art Nouveau Era Tahun 1809-1920 dengan Metode Peta Morfologi
}

\author{
Devanny Gumulya, Sisilia Huang, dan Eileen Florean Gunawan \\ Program Studi Desain Produk, Fakultas Desain, Universitas Pelita Harapan, Jakarta, Indonesia \\ e-mail: devanny.gumulya@uph.edu
}

\begin{abstract}
Abstrak - Peta morfologi berasal dari keilmuan teknik. Artikel ini mempelajari cara menerapkannya dalam proses desain kreatif yang memungkinkan pemikiran yang berbeda dan logis untuk digunakan secara bersamaan. Selanjutnya dibahas karya mahasiswa desain produk yang merancang dengan menggunakan grafik morfologi. Sejarah, bagaimanapun, telah mengilhami banyak desainer untuk menciptakan banyak hal baru. Art Nouveau adalah sebuah gerakan seni arsitektur dan dekoratif yang lahir dan berpusat di Eropa Barat sekitar tahun 1809 - 1920 berawal dari Paris dan menyebar ke Amerika Serikat dan wilayah Eropa lainnya. Salah satunya adalah Catalan, juga dikenal sebagai Art Nouveau Catalan, gerakan seni dari wilayah Catalan (Barcelona, Girona, Lleida, Tarragona). Garis asimetris dan bergelombang, bentuk alami (organik) seperti tangkai, kuncup bunga, tanaman merambat dan sayap serangga adalah ciri khas Art Nouveau Catalan untuk memberikan kesan elegan. Sementara Art Nouveau $A S$ terkenal dengan mosaik kaca organik. Tujuan dari studi ini adalah untuk mencapai kaca dan desain lampu dinding yang menggabungkan elemen Art Nouveau dengan preferensi mahasiswa desain produk. Hasil riset adalah kerangka untuk menggunakan grafik morfologi dalam proses desain proyek jangka pendek. Luaran akhir artikel ini menghasilkan 11 (sebelas) ide desain produk baru.
\end{abstract}

Kata Kunci-Sejarah desain produk, inspirasi, era, peta morfologi, dan proses desain.

Abstract-Morphology charts come from engineering discipline, this paper studies how to apply them in a creative design process that allows divergent and logical thinking to be used simultaneously. The paper discusses product design students' work to design using morphological charts. History, however, has inspired many designers to create many new things. Art Nouveau is an architectural and decorative art movement that was born and centered in Western Europe around 1809 - 1920 from Paris and spread to the US and other regions of Europe. One of them is Catalan, also known as Art Nouveau Catalan, art movements from the Catalan region (Barcelona, Girona, Lleida, Tarragona). Asymmetrical and wavy lines, natural (organic) forms like stalks, flower buds, vines and insect wings are unique works of Art Nouveau Catalan to give an elegant impression. While Art Nouveau US is renowned for organic glass mosaics. The paper objective is to achieve glassware and wall lamp design combining Art Nouveau elements with product design student preferences. The result of this paper is a framework for using morphological charts in a short-term project design process. This exercise produces 11 (eleven) new product design ideas.

Keywords-history of design, inspiration, era, morphological chart, and design process.

\section{PENDAHULUAN}

Sebuah perusahaan agar tetap kompetitif dipasar harus terus melakukan inovasi baik dari segi produk, jasa, ataupun model bisnisnya. Pasar selalu mencari kebaruan, contohnya di era 1950-an konsumen berlomba-lomba melihat mobil baru di dealer di Detroit [1]. Di tahun 1960-an, para remaja dengan senantiasa menunggu lagu band favorit yang terbaru diputar di radio. Sekarang konsumen berbondong-bondong setia antri di depan toko Apple untuk mendapatkan ponsel selular iphone yang terbaru. Kita dengan setia menunggu Netflix mengeluarkan film seri terbaru yang dapat ditonton.

Para ilmuwan mengatakan bahwa manusia selalu mencari kebaruan, karena dengan menemukan dan mempelajari sesuatu yang baru maka hormon dopamin di otak yang bertanggung jawab memberikan rasa kebahagiaan aktif dan bereaksi $[2,3,4]$.

Pasar mempersepsikan kebaruan produk dalam dua dimensi [5]:

1. Pandangan beriorientasi pada produk

Produk baru akan cukup dikatakan baru dari produk sebelumnya bila memberikan fitur baru, tampilan estetika yang baru, dan kebaruan teknologi.

2. Pandangan beriorientasi pada proses

Seberapa besar faktor eksternal seperti orang, proses dan lingkungan mempengaruhi proses sebuah perusahaan membuat produk yang baru.

Dengan adanya kebutuhan dari pasar untuk selalu ingin mencari yang baru, desainer dituntut berpikir kreatif untuk menghasilkan desain yang unik dan memiliki unsur kebaruan dari segi bentuk, konsep dan proses pembuatannya. Di sisi lain sejarah selalu menginspirasi desainer, dikatakan bahwa kita akan melangkah lebih cepat bila kita memahami masa kini [6]. Pernyataan ini membawa makna yang mendalam: kita tidak dapat menciptakan sesuatu dengan tidak belajar masa lalu. Dengan tidak memahami masa lalu, kita akan terus mengulangi kesalahan yang sama yang menghambat kemajuan. Oleh karena itu, sejarah selalu menjadi inspirasi yang terus diulik desainer di berbagai bidang. Sebagai contoh (Gambar 1), seorang desainer fesyen yang terinspirasi oleh sejarah adalah Vivianne Westwood pada tahun 1970-an dengan punk subkultur. Ia menciptakan koleksi fashion, yang membuat met museum memberinya gelar ibu punk [7]. 

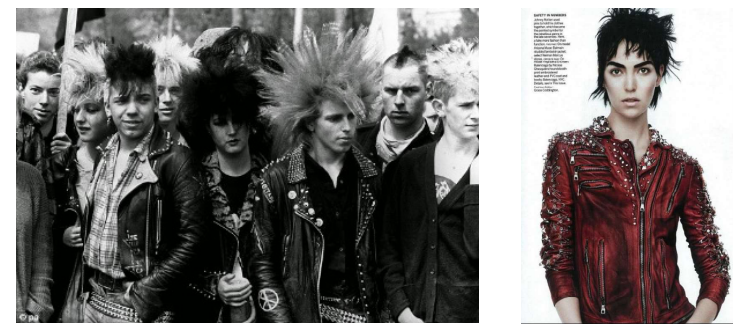

Gambar 1. Punk Vivienne Westwood Collection.

Sumber: https://www.metmuseum.org/toah/hd/vivw/hd_vivw.htm

Proses bagaimana mahasiswa desain produk, melakukan proses kreasi mencari kebaruan dalam desain dengan menerapkan metode peta morfologi dengan menggunakan fakta sejarah sebagai inspirasi untuk mencari kebaruan dalam desain akan dijelaskan. Fakta sejarah yang dijadikan inspirasi adalah sebuah gaya desain Art Nouveau. Kata "Art Nouveau" sendiri dalam bahasa Perancis berarti "Seni Baru". Art Nouveau mencapai puncak popularitas pada awal abad 20. Seni Art Nouveau membawa tema "Kembali ke Alam". Oleh karena itu, tarikan garis dan bentuk Art Nouveau diambil dari alam meliputi flora dan fauna. Art Nouveau masuk pada seni dekoratif dan arsitektur di akhir abad ke-19 dan awal abad ke-20. Terdapat antusiasme yang besar untuk gerakan ini di seluruh Eropa dan sekitarnya. Ditujukan untuk memodernisasi desain, untuk menjauh dari gaya historis yang sebelumnya populer. Seniman mendapatkan inspirasi dari bentuk organik dan geometris, mengembangkan desain elegan yang menyatukan bentuk alami yang mengalir dengan kontur yang lebih bersudut. Era ini merupakan awalan bagi seniman lainnya mendapat kebebasan dalam berkarya tanpa aturan tertentu, dengan meninggalkan era bernuansa agama dan menghidupkan kembali budaya-budaya klasik.

Gaya Art Nouveau menyebar secara menyeluruh di arsitektur, interior, seni dekorasi, dan desain grafis. Kemajuan teknologi dan penggunaan bahan yang baru juga membuat para desainer dapat bereksplorasi lebih jauh dengan menggunakan besi tempa, keramik, dan kaca. Semua bidang seni harus ditampilkan dengan harmonis untuk menghasilkan karya seni yang menyeluruh (holistik), oleh karena itu mulai dari arsitektur, interior hingga objek dekorasi menggunakan karakter elemen desain yang sama. Walaupun gerakan ini terpisah-pisah di beberapa Negara dan masing-masing memiliki namanya sendiri, namun semuanya memiliki spirit desain yang sama, yaitu: pencarian bentuk baru, konsep harmoni total work of art, serta alam sebagai sumber inspirasi [8]. Di Austria Art Nouveau dikenal dengan Seccession, di Jerman dikenal dengan Jugendstill, namun semuanya memiliki spirit desain yang sama, yaitu: pencarian bentuk baru, konsep harmoni total work of art, serta alam sebagai sumber inspirasi. Di Spanyol, Perancis, dan Amerika, desain Art Nouveau didominasi oleh garis-garis lengkung yang sangat dinamis. Di Scotland, Inggris dan Jerman, didominasi oleh garis-garis lurus. Karya Charles Renie Mackintosh (Inggris) adalah contoh dari gaya Art Nouveu yang kaku. Gaya ini diaplikasikan dalam seni, arsitektur, tekstil, pakaian, perhiasan, furnitur serta perabot logam dan ilustrasi buku serta berbagai barang cetakan.

Studi ini secara khusus akan mengambil inspirasi dari Gerakan Art Nouveau yang terjadi di Amerika Serikat dan Catalan (Barcelona, Girona, Lleid, dan Terraguna).
Selanjutnya elemen desain dari karya Art Nouveau Catalan dan Amerika dijadikan sebagai inspirasi dalam perancangan desain produk (Lihat Tabel 1, 2 dan 3). Karena gaya Art Nouveau di kedua wilayah ini jarang diulik dan dibahas daripada gerakan Art Nouveau yang terjadi di Perancis.

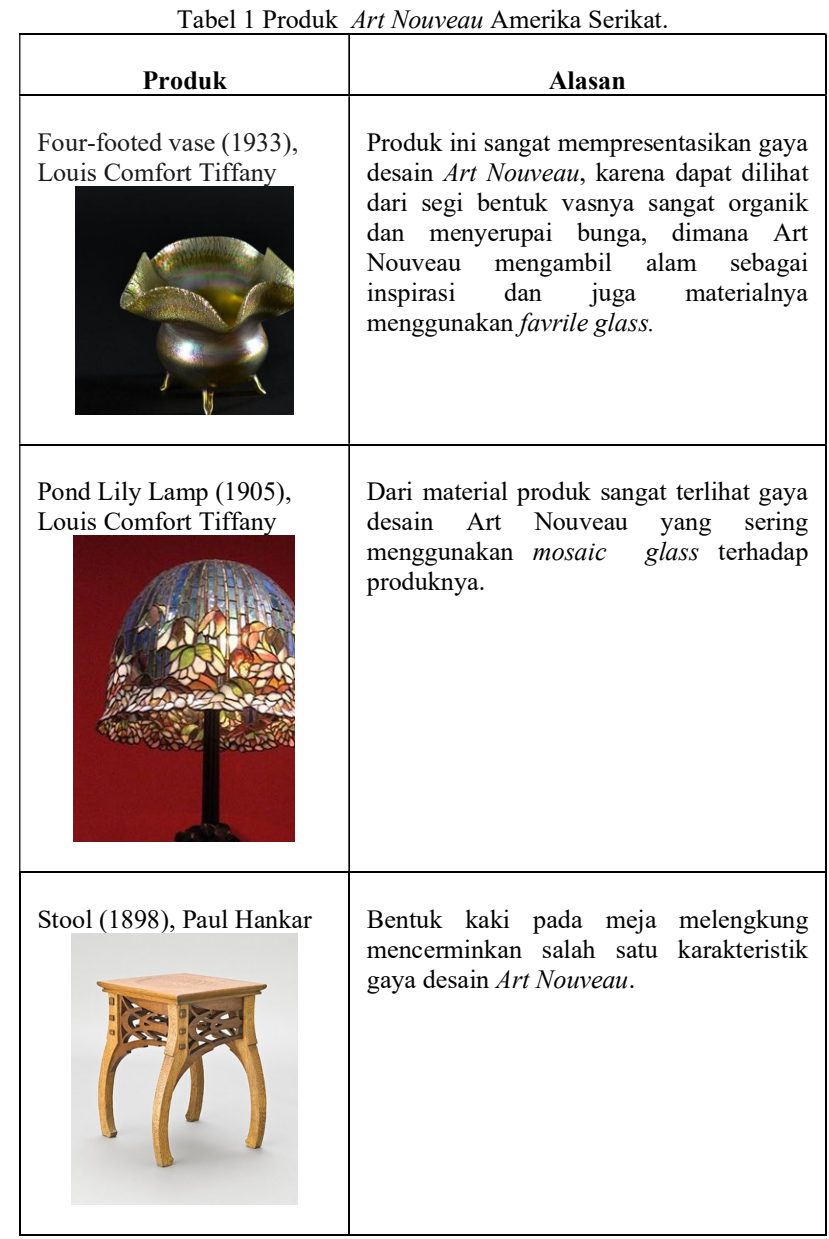

Material yang mempresentasikan gaya desain Art Nouveau yaitu material favrile glass dan mosaic glass. Kedua material yang paling sering digunakan dalam karya produk Art Nouveau US salah satu desainer ialah Louis Comfort Tiffany.

Tabel 2 Konteks Politik, Ekonomi, Sosial, dan Teknoplogi (PEST) Art Nouveau Amerika Serikat.

\begin{tabular}{|l|l|}
\hline \multicolumn{2}{|l|}{ Latar Belakang PEST di Amerika } \\
\hline Politik & $\begin{array}{l}\text { Tahun 1880, masa dimana Art Nouveau mulai } \\
\text { berkembang di Amerika, pada 28 Juli 1914, perang } \\
\text { dunia 1 terjadi di Eropa dan berakhir pada 11 } \\
\text { November 1918. Walau Amerika tidak berpartisipasi } \\
\text { pada perang dunia 1 namun perang ini memberikan } \\
\text { dampak kepada Amerika. }\end{array}$ \\
\hline Ekonomi & $\begin{array}{l}\text { Perekonomian di Amerika terus meningkat karena } \\
\text { pabrik industri berkembang pesat. Amerika terus } \\
\text { memproduksi banyak mesin-mesin industri untuk } \\
\text { dijual. }\end{array}$ \\
\hline Sosial & $\begin{array}{l}\text { Art Nouveau menerima dengan terbuka bahan-bahan } \\
\text { fabrikasi dan juga penggunaan mesin untuk } \\
\text { menghasilkan karya-karya artistik. }\end{array}$ \\
\hline Teknologi & $\begin{array}{l}\text { Revolusi industri yang terjadi di Amerika menciptakan } \\
\text { banyak teknologi seperti mesin jahit, mesin tik, dll yang } \\
\text { mempermudah para seniman menghasilkan produk } \\
\text { seni. }\end{array}$ \\
\hline
\end{tabular}


Tabel 3 . Elemen Desain dan Paradigma Art Nouveau US

\begin{tabular}{|c|c|}
\hline Elemen Desain & Paradigma \\
\hline $\begin{array}{l}\text { Form : Asimetris, } \\
\text { melengkung }\end{array}$ & \multirow{7}{*}{$\begin{array}{l}\text { Para desainer Art Nouveau percaya semua } \\
\text { bidang seni harus ditampilkan dengan harmonis } \\
\text { untuk menghasilkan karya seni yang } \\
\text { menyeluruh (holistic), oleh karena itu mulai dari } \\
\text { arsitektur, interior hingga objek dekorasi } \\
\text { menggunakan karakter elemen desain yang } \\
\text { sama. }\end{array}$} \\
\hline $\begin{array}{l}\text { Shape : Organik, } \\
\text { tumbuh-tumbuhan }\end{array}$ & \\
\hline $\begin{array}{l}\text { Material : Besi } \\
\text { tempa, kaca }\end{array}$ & \\
\hline $\begin{array}{l}\text { Proportion : } \\
\text { Asimetris }\end{array}$ & \\
\hline $\begin{array}{l}\text { Texture : Mosaic } \\
\text { Glass, Favrile } \\
\text { Glass }\end{array}$ & \\
\hline $\begin{array}{l}\text { Surface : } \\
\text { Dekoratif }\end{array}$ & \\
\hline $\begin{array}{l}\text { Color: Warna- } \\
\text { warni }\end{array}$ & \\
\hline
\end{tabular}

\section{Penjelasan material}

\section{Favrile Glass}

Favrile Glass adalah salah satu jenis kaca yang ditemukan oleh Louis Comfort Tiffany. Kaca cair diolah dengan oksida logam yang diserap ke dalam gelas dan menciptakan efek permukaan warna-warni yang khas. Pada awal 1890-an, bekerja dengan Arthur Nash, pembuat kaca Inggris dari Stourbridge England, ia menemukan metode untuk memadukan berbagai warna kaca dalam keadaan cair di tungku. Mereka juga mencampurkan kaca dengan berbagai oksida logam dan memaparkannya pada asap asam sehingga menghasilkan kilau dan efek cahaya yang lebih cemerlang. Tiffany menamakan jenis gelas favrile ini, dari kata Inggris Kuno 'fabrile' atau buatan tangan.

\section{Mosaic Glass}

Mosaik tradisional terbuat dari kaca-kaca kecil yang dipotong kira-kira dari potongan kaca persegi atau enamel kaca buatan tangan dengan warna berbeda. Kaca bermotif (kaca mosaik), dari potongan- potongan kaca tersebut lalu direkatkan atau digabungkan sehingga didapatkan gambar perincian menurut rencana yang memuat pembagian dan warna-warna yang berbeda-beda atau warna-warni, perpotongan dengan ukuran yang sebenarnya (Tabel 4).

Selanjutnya proses pembuatan Mosaic Glass dapat dilihat pada Tabel 4. Dapat disimpulkan dari tabel hasil analisa gaya desain Art Nouveau US tersebut, bahwa Art Nouveau memiliki karakteristik yaitu garis melengkung, asimetris, menggunakan warna-warna yang cerah dan warna-warni. Art Nouveau juga memiliki karakteristik bentuk yang organik pada karyanya maupun produknya dan mengambil alam sebagai inspirasi. Art Nouveau juga terkenal menggunakan material favrile glass dan mosaic glass. Jadi, keunikan desain yang ingin ditampilkan dalam perancangan glassware ini ialah menggunakan material kaca (Mosaic Glass dan Favrile Glass ) yang akan menjadi elemen yang utama pada perancangan glassware ini serta mengkombinasikannya dengan material besi tempa yang merupakan salah satu material yang mempresentasikan dan sangat sering digunakan dalam produk atau karya Art Nouveau. Selanjutnya dapat dilihat Tabel 5 dan Gambar 2.

\section{METODE}

Peta morfologi adalah metode untuk menghasilkan ide-ide secara analitis dan sistematis. Membuat morphological chart untuk membuat beberapa alternatif dan memilih alternatif terbaik untuk mencapai desain yang ingin dicapai (Gambar 3). Di dalam chart ini dibuat kombinasi dari berbagai kemungkinan solusi untuk merancang produk-produk yang berbeda dan bervariasi. Kombinasi yang berbeda dari sub solusi dapat dipilih dari chart mungkin dapat menuju solusi yang belum teridentifikasi atau terpecahkan sebelumnya. Morphological chart berisi komponen-komponen dan ideide yang dapat dikombinasikan [9]. Hal ini juga merupakan suatu cara dalam mengembangkan atau mewujudkan banyaknya pemikiran yang kreatif terutama suatu kreatifitas seringkali dapat dipandang sebagai suatu penggabungan kembali elemen-elemen yang ada [10 dan 11]. Tujuan utama dari metode ini ialah untuk memperluas perancangan terhadap solusi baru yang mungkin.

Tabel 4 Proses pembuatan Mosaic Glass

\begin{tabular}{|c|c|}
\hline Proses & Referensi \\
\hline $\begin{array}{l}\text { 1. Membuat pola yang ingin } \\
\text { dibuat menjadi mosaic dari } \\
\text { kaca. }\end{array}$ & \\
\hline $\begin{array}{l}\text { 2. Memotong kaca sesuai } \\
\text { pola satu persatu. }\end{array}$ & \\
\hline $\begin{array}{l}\text { 3. Setiap potongan kaca } \\
\text { dikelilingin dengan } \\
\text { lembaran tembaga (copper } \\
\text { foil). }\end{array}$ & \\
\hline $\begin{array}{l}\text { 4. Potongan kaca yang sudah } \\
\text { diberi lembaran tembaga } \\
\text { dicocokan kembali dengan } \\
\text { pola asalnya, untuk } \\
\text { memastikan bentuknya } \\
\text { masih sempurna. }\end{array}$ & \\
\hline $\begin{array}{l}\text { 5. Potongan kaca disatukan } \\
\text { dengan memanasan } \\
\text { lembaran tembangan } \\
\text { dengan solder satu persatu } \\
\text { di cetakan kayu. }\end{array}$ & \\
\hline $\begin{array}{l}\text { 6. Potongan kaca yang sudah } \\
\text { disatukan dengan bentuk } \\
\text { dari cetakan. }\end{array}$ & \\
\hline
\end{tabular}


Ada pula prosedur pelaksanaan metode Morphological Chart antara lain:

1. Buat daftar hal-hal penting atau fungsi-fungsi yang penting untuk produksi. Daftar jangan terlalu panjang, dan harus secara luas mencakup fungsifungsinya.

2. Untuk tiap hal atau fungsi, buat daftar cara-cara yang dapat dicapai oleh tiap fungsi. Daftar ini dapat mencakup ide-ide baru yang dikenal baik sebagai komponen-komponen atau sub-sub solusi yang sudah ada.

3. Gambarkan sebuah peta yang berisi semua sub-sub solusi yang mungkin.

4. Identifikasi kombinasi sub-sub solusi yang dapat dijalankan.

Tabel 5 Elemen Desain Material Art Nouveau US

\begin{tabular}{|c|l|l|}
\hline \multicolumn{1}{|c|}{ Tabel 5 Elemen Desain Material Art Nouveau US } \\
\hline \multirow{3}{*}{ Elemen Desain } & $\begin{array}{l}\text { Menggunakan } \\
\text { warna cerah: } \\
\text { Marna }\end{array}$ \\
\hline \multirow{5}{*}{ Material } & $\begin{array}{l}\text { Menggunakan } \\
\text { material yang } \\
\text { mempresentasikan } \\
\text { Art Nouveau: } \\
\text { 1. Mosaic Glass } \\
\text { 2. Favrile Glass } \\
\text { 3. Wrough Iron }\end{array}$ \\
\hline Tekstur & $\begin{array}{l}\text { Tekstur dari mosaic } \\
\text { glass, favrile glass } \\
\text { dan wrought iron }\end{array}$ \\
\hline Bentuk & $\begin{array}{l}\text { Tidak kaku, } \\
\text { melengkung, dan } \\
\text { sederhana }\end{array}$ \\
\hline
\end{tabular}

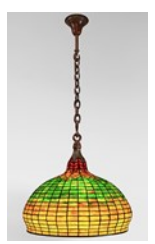

Geometric

Brick

1905

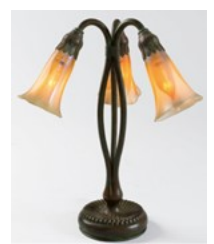

$$
\text { Three Light Lily }
$$

1900

Gambar 2. Karya Art Nouveau Catalan Sumber: metmuseum.org

\section{HASIL DAN PEMBAHASAN}

Dari Tabel 5 dan Gambar 3 selanjutnya dapat dihasilkan beberapa ide desain dengan menggabungkan antara elemen kolom dan baris.

Produk pertama yang didesain dengan inspirasi Art Nouveau
US adalah home décor.

Latar Belakang PEST Art Nouveau Catalan:

\section{Politik}

Art Nouveau Catalan ini terjadi karena munculnya gerakan yang ingin membuat masyarakat Catalan menjadi masyarakat yang modern dan juga menolak gagasan burjois yang muncul pada masa itu.

\section{Ekonomi}

Banyak masyarakat yang pindah kedaerah perkotaan dengan tujuan mencari pekerjaan membuat kondisi kota jadi padat sehingga pemerintah memutuskan untuk membangun exiample (kawasan distrik yang tertata rapi dan padat).

\section{Sosial}

Pada masa ini masyarakat memiliki pemikiran untuk lepas dari tradisi dan juga lebih menggunakan pemikiran dari pada menggunakan gaya Baroque dan Gothic. Gaya baru yang digunakan itu terinspirasi dari alam baik dalam bentuk, danwarna atau lainnya

\section{Teknologi}

Adanya revolusi industri menciptakan mesin-mesin yang mendukung para seniman untuk membuat karya yang lebih berkembang. Mesin untuk mengolah besi ditemukan sehingga yang biasanya menggunakan bahan kayu, dapat diganti dengan menggunakan bahan besi.

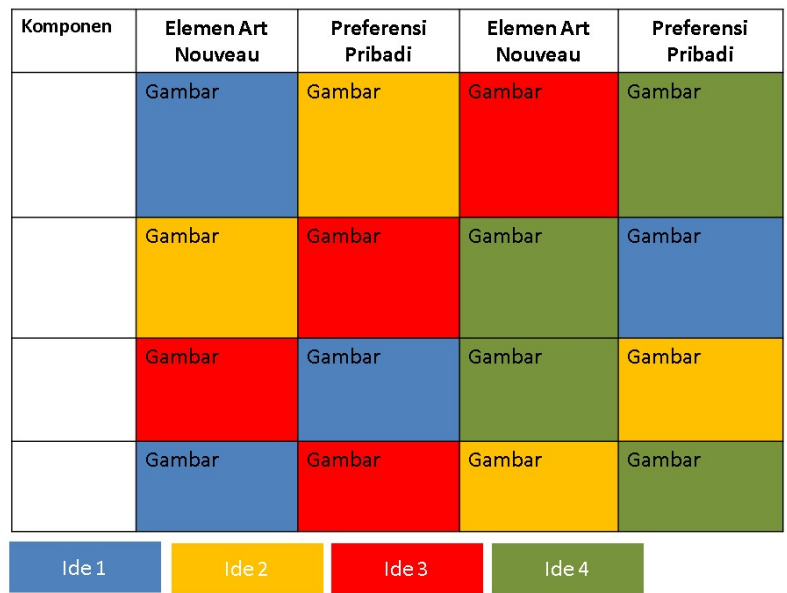

Gambar 3. Metode Morphpological Chart.

Tabel 6 Komponen ide desain Glassware 1.

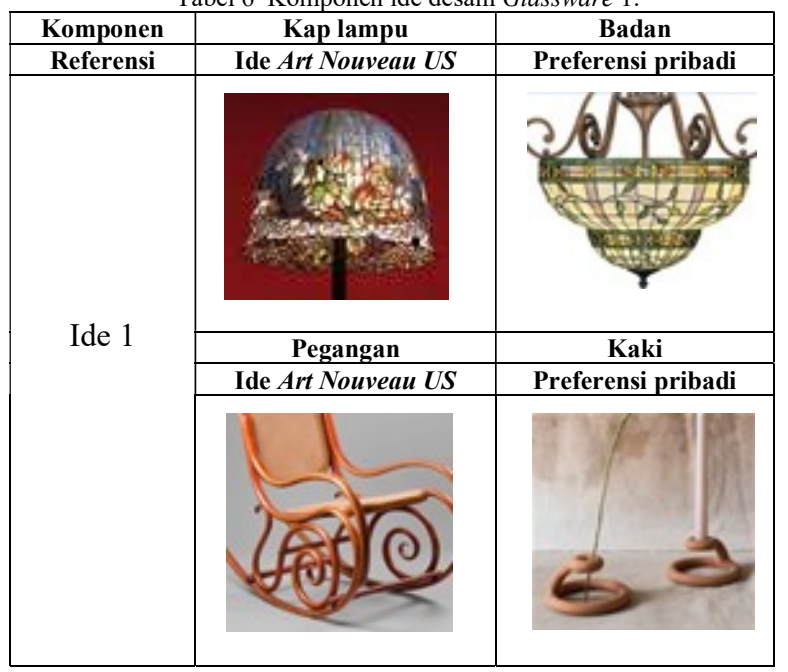




\section{Desain Glassware 1}

Tabel 6 menjelaskan proses desain Glassware 1, dikembangkan dengan menggabungkan elemen Art Nouveau $U S$ dengan preferensi pribadi.

Selanjutnya dihasilkan desain Glassware seperti dapat dilihat pada Gambar 4.
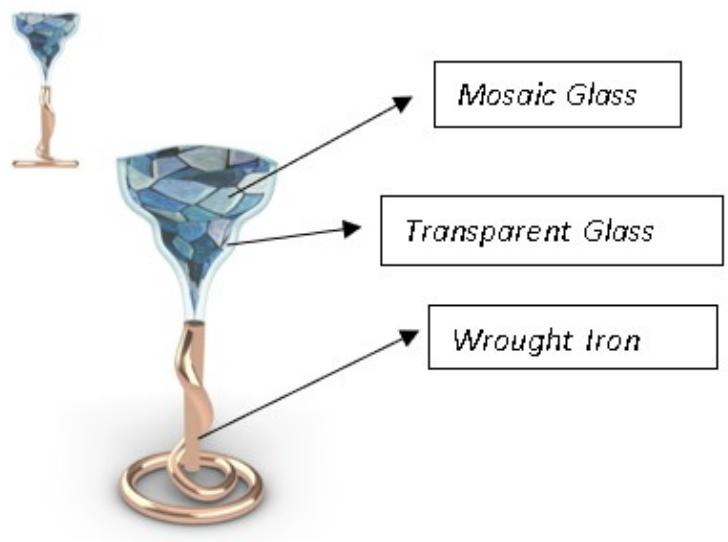

Gambar 4 Desain Glassware 1.

Desain Glassware 2

Proses desain Glassware 2 dikembangkan dengan menggabungkan elemen Art Nouveau US dan preferensi pribadi seperti dapat dilihat pada Tabel 7.

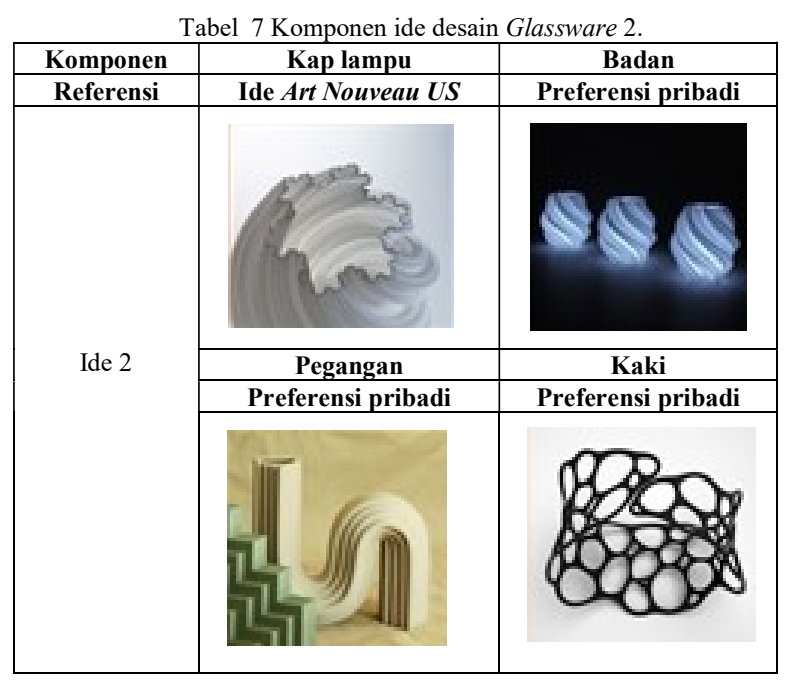

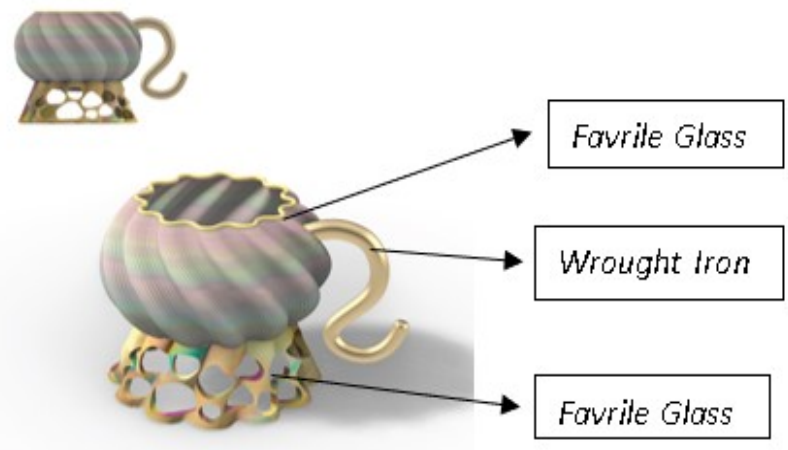

Gambar 5 Desain Glassware 2.
Gambar 5 menunjukkan desain Glassware 2 dari hasil proses desain sebelumnya.

\section{Desain Glassware 3}

Pengembangan desain Glassware 3 dengan menggabungkan elemen Art Nouveau US dan preferensi pribadi dapat dilihat pada Tabel 8. Desain akhir Glassware 3 dapat diapresiasi pada Gambar 6.

\begin{tabular}{|c|c|c|}
\multicolumn{2}{c}{ Tabel 8 Komponen ide desain Glassware 3. } \\
\hline Komponen & Kap lampu & Badan \\
\hline Referensi & Preferensi pribadi & Preferensi pribadi \\
\hline \multirow{5}{*}{ Ide 3 } & & \\
\cline { 2 - 4 } & & \\
\cline { 2 - 4 } & Ide Art Nouveau US & Ide Art Nouveau US \\
\cline { 2 - 3 } & & \\
\hline & & \\
\hline
\end{tabular}
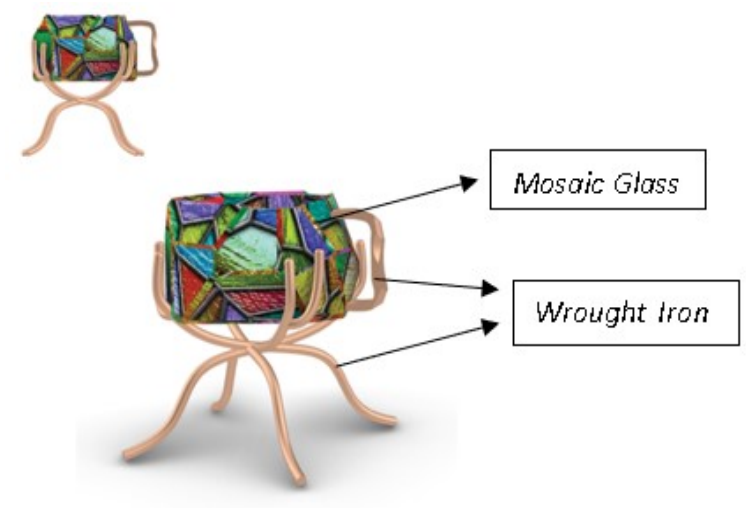

Gambar 6 Desain Glassware 3.

Tabel 6 Komponen Ide Desain Glassware 4.

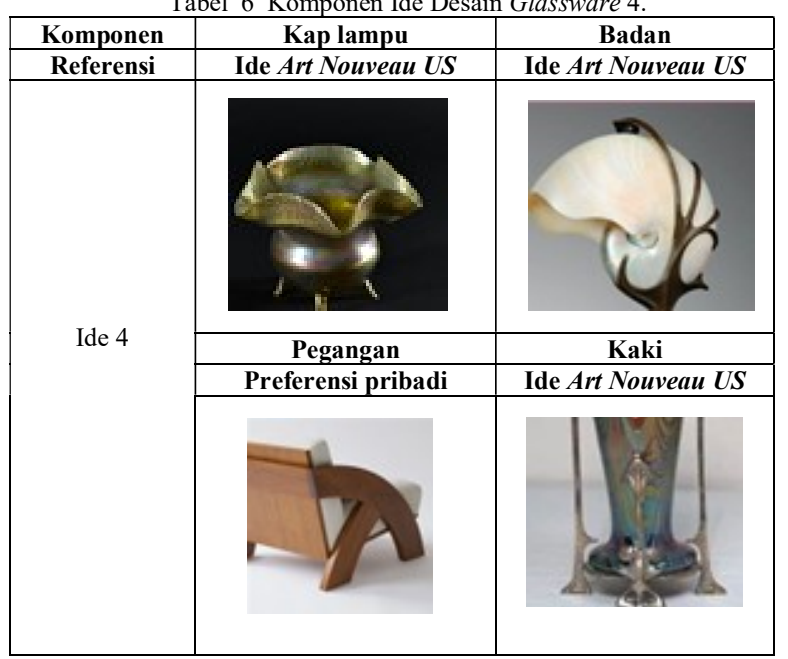


Devanny Gumulya, Sisilia Huang, dan Eileen Florean Gunawan

Perancangan Desain Produk Dengan Inspirasi Art Nouveau Era Tahun 1809-1920 dengan Metode Peta Morfologi

\section{Desain Glassware 4}

Mengacu pada Tabel 11 desain Glassware 4 (Gambar 7) dikembangkan dengan menggabungkan elemen art nouveau US dan preferensi pribadi.

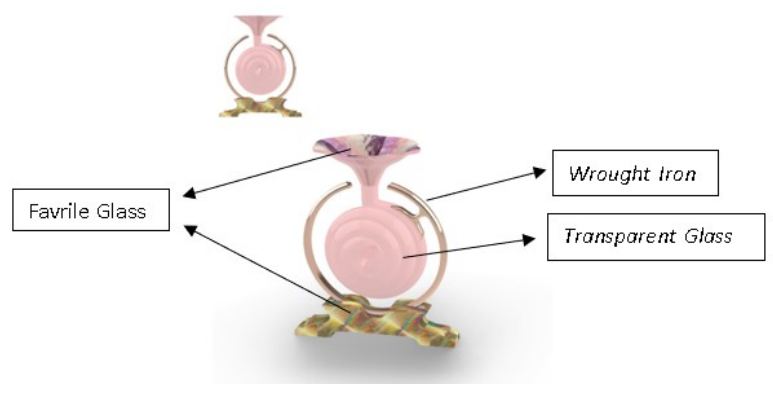

Gambar 7 Desain Glassware 4

Desain Glassware 5

Mengacu pada Tabel 12 desain Glassware 5 (Gambar 8) dikembangkan dengan menggabungkan elemen art nouveau US dan preferensi pribadi.

Tabel 7 Komponen Ide Desain Glassware 5.

\begin{tabular}{|c|c|c|}
\hline Komponen & Kap lampu & Badan \\
\hline Referensi & Ide Art Nouveau US & Ide Art Nouveau US \\
\hline \multirow{5}{*}{ Ide 5 } & & \\
\cline { 2 - 3 } & Ide Art Nouveau US & Preferensi Pribadi \\
\cline { 2 - 3 } & Pegangan & \\
\cline { 2 - 3 } & & \\
\hline
\end{tabular}
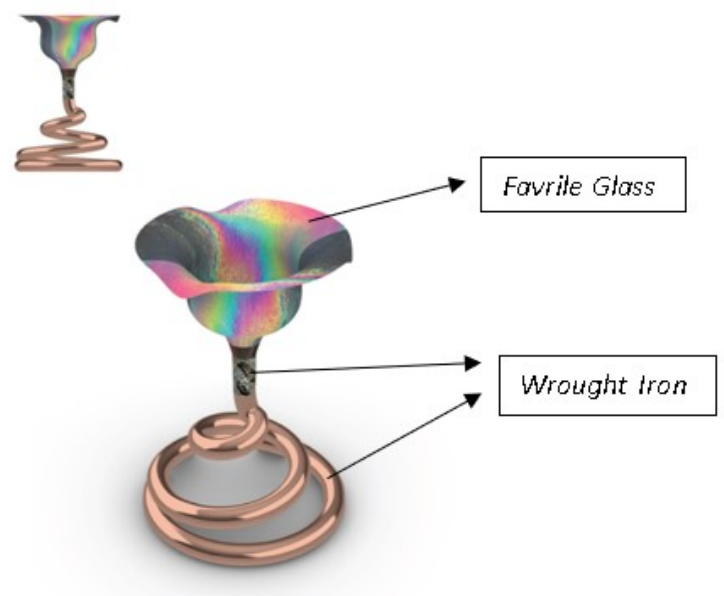

Gambar 8 Desain Glassware 5

Selanjutnya, produk kedua yang didesain dengan inspirasi Art Nouveau Catalan adalah lampu dinding.

\section{Desain Lampu Dinding 1}

Mengacu pada Tabel 13 desain lampu dinding 1 (Gambar
9) dikembangkan dengan menggabungkan elemen art nouveau Catalan dan preferensi pribadi.

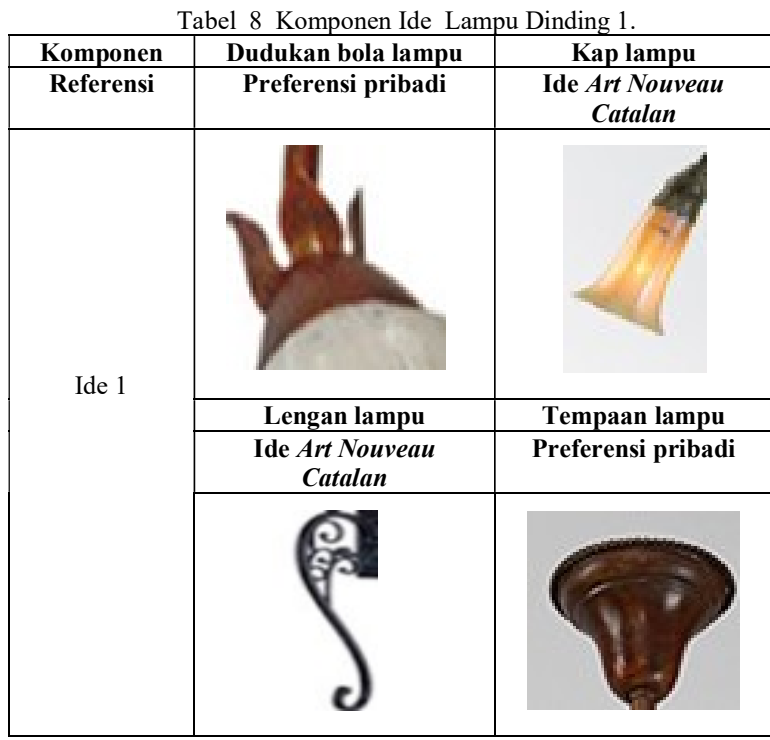

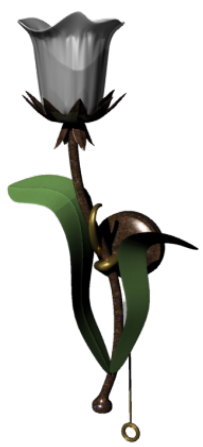

Gambar 9 Desain Lampu Dinding 1

Desain Lampu Dinding 2

Mengacu pada Tabel 14 desain lampu dinding 2 (Gambar 10) dikembangkan dengan menggabungkan elemen art nouveau Catalan dan preferensi pribadi.

Tabel 9 Komponen Ide Lampu Dinding 2.

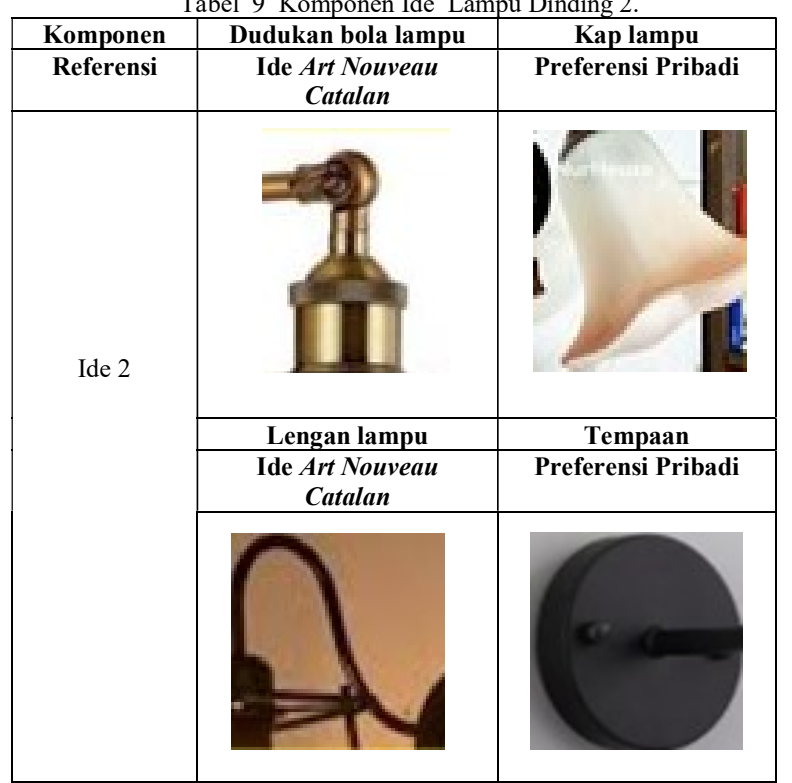




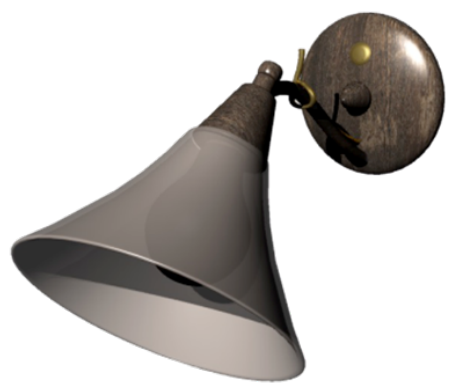

Gambar 10 Desain Lampu Dinding 2

Desain Lampu Dinding 3

Mengacu pada Tabel 15 desain lampu dinding 3 (Gambar 11) dikembangkan dengan menggabungkan elemen art nouveau Catalan dan preferensi pribadi.

Tabel 10 Komponen Ide Lampu Dinding 2.

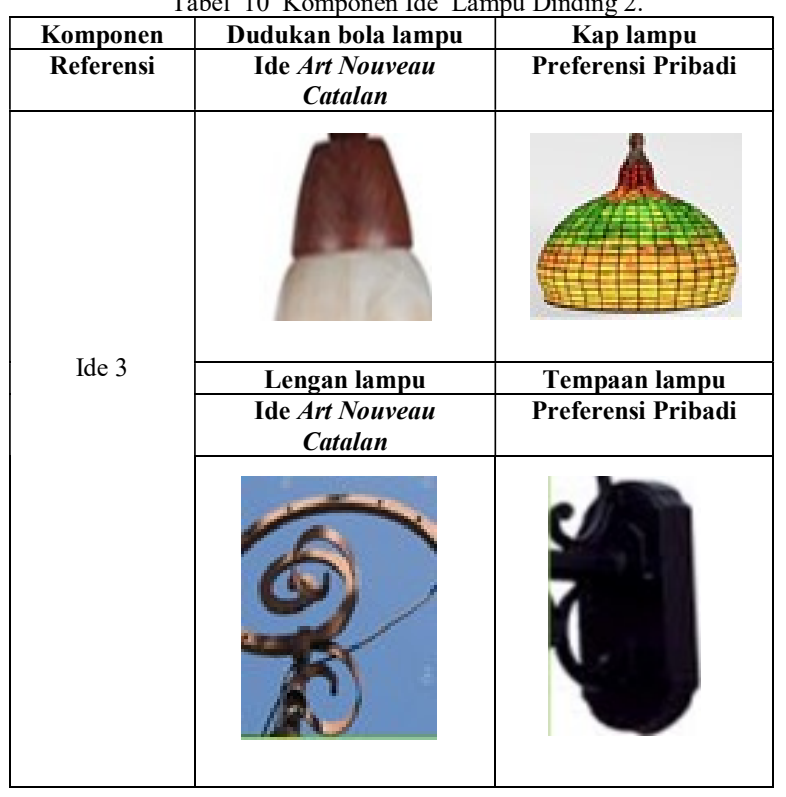

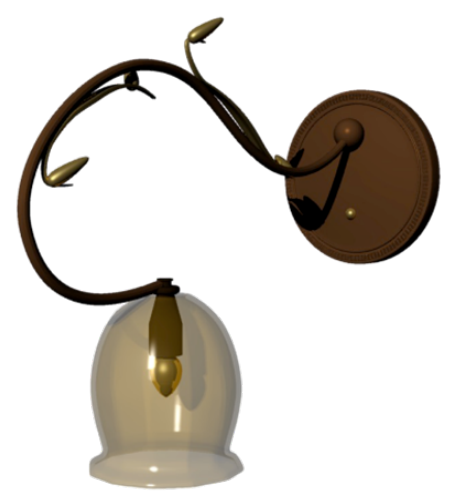

Gambar 11 Desain Lampu Dinding 3.

\section{Desain Lampu Dinding 4}

Mengacu pada tabel 16 desain lampu dinding 4 (Gambar 12) dikembangkan dengan menggabungkan elemen art nouveau Catalan dan preferensi pribadi.
Tabel 11 Komponen Ide Lampu Dinding 4.

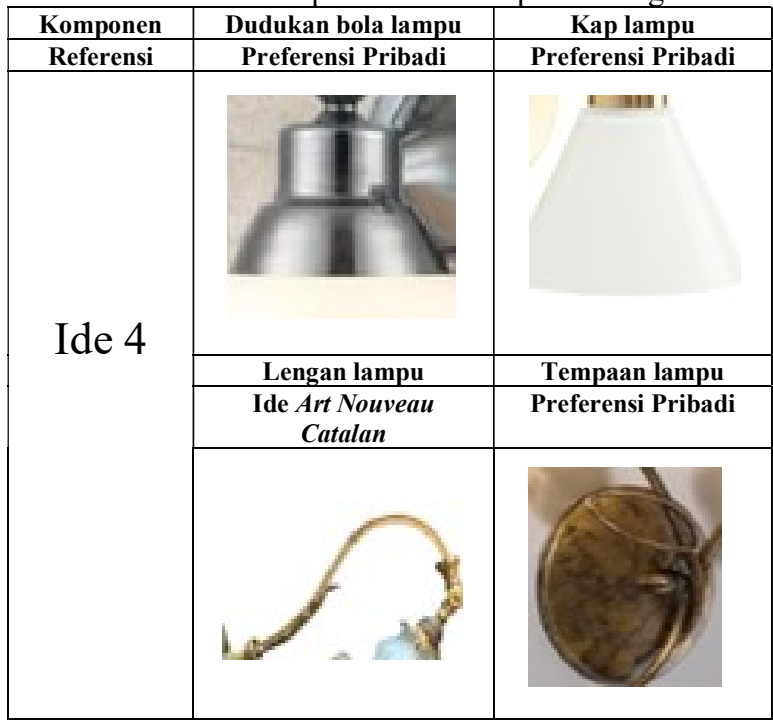

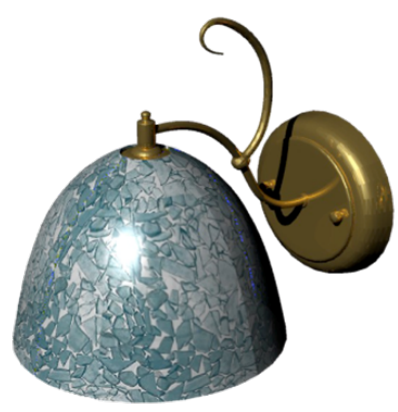

Gambar 12 Desain Lampu Dinding 4.

Desain Lampu Dinding 5

Mengacu pada Tabel 17 desain lampu dinding 5 (Gambar 13) dikembangkan dengan menggabungkan elemen art nouveau Catalan dan preferensi pribadi.

Tabel 12 Komponen Ide Lampu Dinding 5

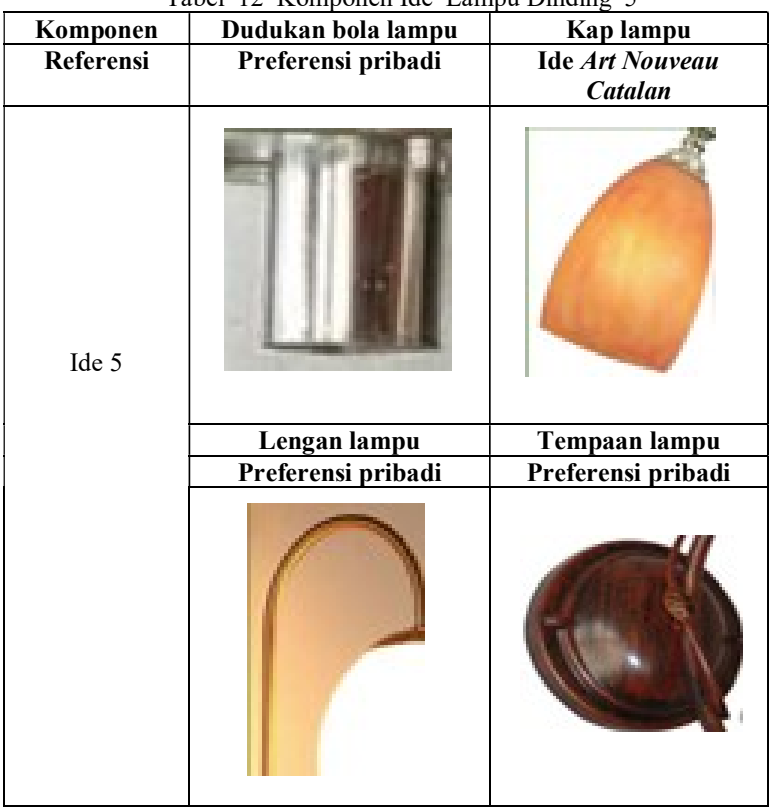




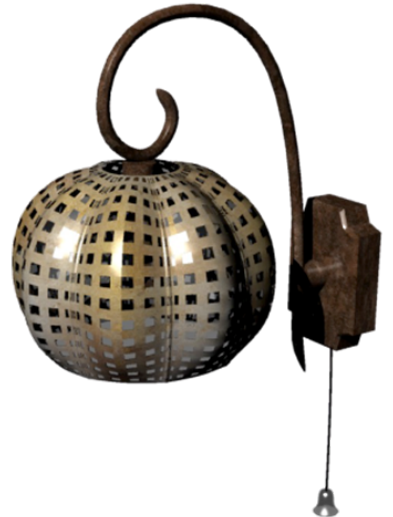

Gambar 13 Desain Lampu Dinding 5.

\section{Desain Lampu Dinding 6}

Mengacu pada Tabel 18 desain lampu dinding 6 (Gambar 14) dikembangkan dengan menggabungkan elemen art nouveau Catalan dan preferensi pribadi.

Tabel 13 Komponen Ide Lampu Dinding 6 .

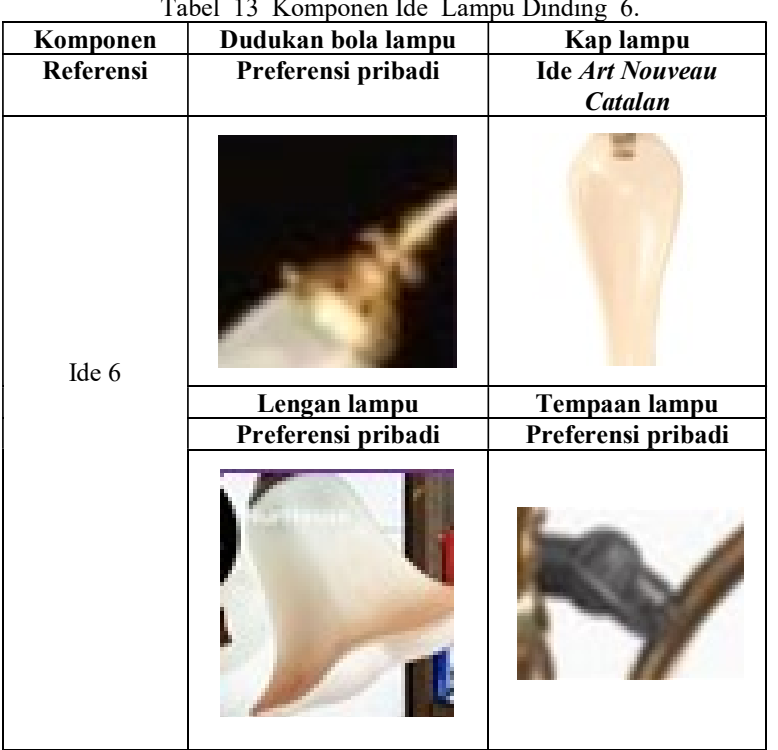

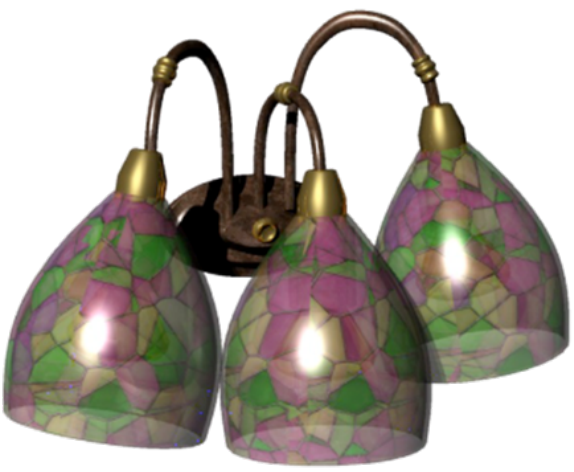

Gambar 14 Desain Lampu Dinding 6.

Dari kesebelas desain baru yang dihasilkan dari inspirasi Art Nouveau US dan Catalan, dapat dilihat kesebelas desain masih menerapkan elemen desain Art Nouveau yang berbentuk organik, tidak bersudut, menggunakan material besi tempa, dan kaca.

\section{KESIMPULAN/RINGKASAN}

Berdasarkan hasil perancangan ini, dapat disimpulkan bahwa perancangan menggunakan metode peta morfologi membuat hasil desain menjadi seimbang antara ide dari Art Nouveau dan preferensi pribadi mahasiswa. Sehingga menghasilkan desain yang saling berkombinasi satu sama lain. Selain itu desainer dapat mentranslasikan setiap inspirasi pada setiap komponen produk secara terstruktur dan sistematis. Misalnya implementasi gaya Art Nouveau pada drawer nakas, knob nakas dan seterusnya.

Selain itu, mendesain dengan menggunakan metode morfologi dalam perancangan membuat proses menjadi lebih terstruktur dengan penetapan komponen bagian bagian yang mencakup produk terlebih dahulu. Semakin banyak kolom x memperkaya ide dan memberikan banyak kemungkinan desain yang baru. Dari studi ini dapat direkomendasikan beberapa hal yang perlu diperhatikan dalam menghasilkan ide dengan peta morfologi adalah sebagai berikut:

1. Kesatuan

Ide desain dengan chart morfologi didapatkan dengan menggabungkan elemen gaya desain dan preferensi mahasiswa desain. Kombinasi elemen yang demikian banyak akan menjadi tantangan bagi mahasiswa bagaimana menyatukan semua elemen itu menjadi satu kesatuan yang saling berharmoni satu sama lain.

\section{Abstraksi}

Kemampuan abstraksi juga menjadi penting, dengan mengabstraksi mahasiswa dapat membuat beberapa elemen menjadi lebih menyatu. Yang ingin dihindarkan mendesain dengan chart morfologi adalah desain menjadi terlihat seperti diambil dari potongan elemen dari berbagai desain.

3. Variasi solusi

Semakin bervariasi komponen yang dimasukkan dalam tabel, ide desain akan menjadi lebih bervariasi. Bila dibandingkan mahasiswa yang mendesain dengan inspirasi Art Nouveau Catalan memasukkan semua inspirasinya dari lampu yang sudah ada, maka dapat diprediksi desain masih terlihat seperti lampu dinding pada umumnya.

\section{UCAPAN TERIMA KASIH}

Penulis mengucapkan terima kasih atas bantuan, bimbingan serta kerjasama dari berbagai pihak yang telah membantu dalam penyusunan karya ilmiah ini kepada Fakultas Desain Universitas Pelita Harapan dan LPPM Universitas Pelita Harapan.

Artikel ini merupakan bagian dari publikasi penelitian internal UPH dengan No. P-091-S-SOD/III/2020 dan terdaftar di LPPM UPH.

\section{DAFTAR PUSTAKA}

[1] Radford, S. K., \& Bloch, P. H. (2011). Linking innovation to design: Consumer responses to visual product newness. Journal of Product Innovation Management, 28(s1), 208-220.

[2] Iyer, E. S. (1988). The influence of verbal content and relative newness on the effectiveness of comparative advertising. Journal of Advertising, 17(3), 15-21. 
[3] Martindale, C., Moore, K., \& West, A. (1988). Relationship of preference judgments to typicality, novelty, and mere exposure. Empirical Studies of the Arts, 6(1), 79-96.

[4] Raghunathan, R., \& Irwin, J. R. (2001). Walking the hedonic product treadmill: Default contrast and mood-based assimilation in judgments of predicted happiness with a target product. Journal of Consumer Research, 28(3), 355-368.

[5] Chakrabarti, A. (2006). Defining and supporting design creativity. In DS 36: Proceedings DESIGN 2006, the 9th International Design Conference, Dubrovnik, Croatia (pp. 479-486).

[6] A quote by Carl Sagan. (n.d.). Retrieved September 14, 2020, from https://www.goodreads.com/quotes/194992-you-have-to-know-thepast-to-understand-the-present.

[7] Vivienne Westwood (born 1941) and the Postmodern Legacy of Punk Style | Essay | The Metropolitan Museum of Art | Heilbrunn Timeline of Art History. (n.d.). Retrieved August 1, 2020, from https://www.metmuseum.org/toah/hd/vivw/hd vivw.html

[8] Asyraf, M. R. M., Ishak, M. R., Sapuan, S. M., \& Yidris, N. (2019). Conceptual design of creep testing rig for full-scale cross arm using TRIZ-Morphological Chart-Analytic Network Process technique. Journal of Materials Research and Technology, 8(6), 5647-5658.

[9] Azammi, A. N., Sapuan, S. M., Ishak, M. R., \& Sultan, M. T. (2018). Conceptual design of automobile engine rubber mounting composite using TRIZ-Morphological chart-analytic network process technique. Defence Technology, 14(4), 268-277.

[10] Null, R. (Ed.). (2013). Universal design: Principles and models. CRC Press.

[11] Gumulya, D., \& Santio, R. (2014). Gaya Art Nouveau Sebagai Inspirasi Dalam Perancangan Desain Produk. Jurnal Dimensi Seni Rupa dan Desain, 11(2), 123-134. 